\title{
Combined radio- and chemotherapy for non-small cell lung cancer: systematic review of landmark studies based on acquired citations
}

\author{
Carsten Nieder ${ }^{1,2}{ }^{*}$, Adam Pawinski ${ }^{1}$ and Nicolaus H. Andratschke ${ }^{3}$ \\ ${ }^{1}$ Department of Oncology and Palliative Medicine, Nordland Hospital, Bodø, Norway \\ 2 Institute of Clinical Medicine, Faculty of Health Sciences, University of Tromsø, Tromsø, Norway \\ ${ }^{3}$ Department of Radiation Oncology, University Hospital Rostock, Rostock, Germany
}

\section{Edited by:}

Søren M. Bentzen, University of Wisconsin School of Medicine and Public Health, USA

\section{Reviewed by:}

Joel S. Greenberger, University of Pittsburgh Medical Center, USA Peter B. Schiff, NYU School of Medicine, USA

\section{*Correspondence:}

Carsten Nieder, Department of Oncology and Palliative Medicine, Nordland Hospital, P.O. Box 1480 , Prinsensgate 164, 8092 Bodo, Norway

e-mail: carsten.nieder@nlsh.no

\begin{abstract}
The important role of combined chemoradiation for several groups of patients with nonsmall cell lung cancer (NSCLC) is reflected by the large number of scientific articles published during the last 30 years. Different measures of impact and clinical relevance of published research are available, each with its own pros and cons. For this review, article citation rate was chosen. Highly cited articles were identified through systematic search of the citation database Scopus. Among the 100 most often cited articles, meta-analyses $(n=5)$ achieved a median of 203 citations, guidelines $(n=7) 97$, phase III trials $(n=29) 168$, phase II trials $(n=21) 135$, phase I trials $(n=7) 88$, and others combined $115.5(p=0.001)$. Numerous national and international cooperative groups and several single institutions were actively involved in performing often cited, high-impact trials, reflecting the fact that NSCLC is a world-wide challenge that requires research collaboration. Platinum-containing combinations have evolved into a standard of care, typically administered concurrently. The issue of radiotherapy fractionation and total dose has also been studied extensively, yet with less conclusive results. Differences in target volume definition have been addressed. However, it was not possible to test all theoretically possible combinations of radiotherapy regimens, drugs, and drug doses (lower radiosensitizing doses compared to higher systemically active doses). That is why current guidelines offer physicians a choice of different, presumably equivalent treatment alternatives. This review identifies open questions and strategies for further research.
\end{abstract}

Keywords: chemoradiation, chemotherapy, citation, non-small cell lung cancer, radiotherapy, research evaluation

\section{BACKGROUND}

Combined radio- and chemotherapy has since the 1980s evolved into a standard of care for a considerable proportion of patients with stage III non-small cell lung cancer (NSCLC) (1-3). Importantly, stage III describes a heterogeneous population with disease presentation ranging from apparently resectable tumors with occult microscopic nodal metastases to unresectable, large volume nodal disease. Even discriminating between stage IIIA and B does not fully resolve this problem. One of the most controversial issues in patients potentially accessible for surgery is the role of neoadjuvant therapy (4). As recently summarized, neoadjuvant therapy followed by surgery is neither clearly better nor clearly worse than definitive chemoradiation (5). Most of the arguments made regarding patient selection for neoadjuvant therapy and surgical resection provide evidence for better prognosis but not for a beneficial impact of this treatment strategy. We will not discuss in greater detail the emerging role of image-guided stereotactic radiotherapy as boost or salvage treatment $(6,7)$ because most data on this modality were derived from studies of stage I NSCLC, where ongoing randomized trials compare surgery to stereotactic radiotherapy (8-11). Both individual institutions and cooperative groups successfully completed an impressive series of clinical trials for advanced NSCLC, many of whom resulted in practicechanging insights. For several reasons including but not limited to tenure track or likelihood of future funding, researchers attempt to publish their results in a way that ensures high visibility and allows for broad adoption of the progress achieved. Landmark studies often appear in prestigious high-impact journals, and are likely to be cited in editorials, reviews, guidelines, etc., (12). Number of acquired citations might be a measure that can be used when performing systematic reviews because it eliminates subjective preferences when selecting influential research to be included (13). For the present review, we relied on citation-based selection of studies, and secondary we hypothesized that randomized clinical trials and meta-analyses acquired more citations than other types of research.

\section{MATERIALS AND METHODS}

A systematic search of the citation database Scopus (Elsevier B.V., www.scopus.com) by use of the term "radiotherapy and lung cancer" was performed on 16th March 2013. Articles were selected irrespective of language, year of publication, and article type (review, guideline, clinical study, experimental study, etc.). In order to determine whether or not a given article reported on NSCLC 
and combined radio- and chemotherapy we accessed its abstract if the title was not sufficiently informative. Then, all articles dealing with the subject of this review were ranked by number of citations (field "times cited" in the Scopus citation database) in order to create a list (top 100) of articles with the highest number of citations. The top 100 articles were reviewed for contents incl. study type (phase I, II, III, retrospective, etc.) and outcomes. Moreover, the following parameters were evaluated: journal in which an article was published, number of authors, and type of research. A complete list of top 100 articles can be requested from the corresponding author.

\section{RESULTS}

The 100 most often cited articles were published between 1984 and 2010 (Figure 1, only three articles were published before 1991). They achieved a median number of 124 citations (range 66-2733). Articles published before 2000 achieved a median of 137 citations (range 66-2733). Those published in the time period 2000-2010 achieved a median of 100 citations (range 66-985). In order to cover the most recent results and trends, we also extracted the top 10 publications from the year 2011 (14-23). They achieved a median of 14.5 citations (range 12-34). References (24-48) represent the 25 most cited articles overall. With regard to the top 100 publications, 3 were written by more than 20 authors. Eight had 15-20 authors, 36 had 10-14 authors, the majority (41) had 5-9 authors, and 12 had less than 5 authors (median number 9, range 1-35). Twenty-nine articles reported on phase III clinical trials (phase II: 21, phase I: 7), five were meta-analyses, seven guidelines, and two literature reviews. The remaining were retrospective and preclinical studies. Meta-analyses achieved a median of 203 citations, guidelines 97, phase III trials 168, phase II trials 135 , phase I trials 88 , and others combined 115.5 ( $p=0.001$, chi square test). Most articles were published in the Journal of Clinical Oncology $(n=43)$, the International Journal of Radiation Oncology Biology and Physics $(n=15)$, the Journal of the National Cancer Institute and the Journal of Thoracic and Cardiovascular Surgery ( $n=5$ each), Clinical Cancer Research and Annals of Thoracic Surgery ( $n=4$ each), as well as Chest $(n=3)$. Five publications on major randomized clinical studies emanated from US or US and Canadian intergroup trials, six from SWOG trials, five from CALGB trials, and four from RTOG trials. Between one and three publications were related to trials performed by ECOG, EORTC, Hoosier Oncology Group, California Cancer Consortium, and different other groups from Australia, China, Europe, and Japan. Cooperative group studies accumulated a median of 154 citations compared to 107 citations for studies not performed by cooperative groups $(p=0.02)$.

\section{DISCUSSION}

The objective of this review was to identify influential, highly cited scientific publications and thereby research mainstreams related to chemoradiation treatment for NSCLC. After arbitrary decisions about which database to search and which keywords to use, we performed a systematic literature search. Citation rate of published articles was evaluated. Articles with high numbers of citations are likely those that impressed other clinicians/scientists and had profound influence on clinical practice or future developments in the

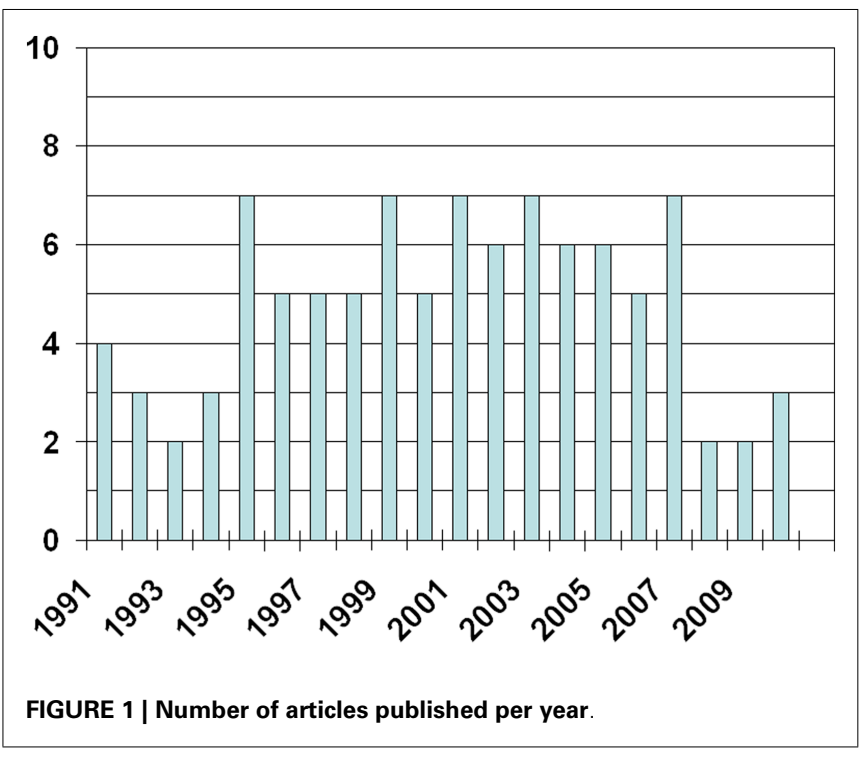

field. It should be noticed that searches in different databases will result in more or less variable citation counts and that the present results therefore provide only a snapshot. Our results are consistent with the assumption that citation rate is gradually increasing for several years after publication. However, the purpose of this overview was not to explore dynamics of citation count. Metaanalyses and phase III trials were the publications accumulating the highest numbers of citations, a finding already described for other types of cancer (13). However, we focused on top 100 articles rather than all meta-analyses and clinical trials on chemoradiation. All major international cooperative groups were actively involved in often cited, high-impact trials, reflecting the fact that NSCLC is a world-wide challenge requiring research collaboration. Cooperative group trials achieved a significantly higher median number of citations compared to other trials. Given the complexity of large clinical trials, which often include companion biomarker studies, and require rapid patient accrual, cooperative groups with their dedicated infrastructure might have advantages in conducting these important studies with potentially practice-changing implications. Typically, convincing phase III data are required before new therapeutic approaches are adopted in the oncology community. However, exceptions from this rule are possible, for example the rapid and widespread use of stereotactic radiotherapy for stage I NSCLC or approval of crizotinib in patients with rearrangements of anaplastic lymphoma kinase (ALK) gene.

The interest in combined modality treatment is old and caused by the fact that neither treatment modality by itself provided satisfactory clinical outcomes. Studies performed in the 1980s often examined non-concomitant approaches [induction chemotherapy followed by radiation (28) or pre and post irradiation chemotherapy (49)]. However, initial concomitant approaches also date back to this time period $(27,50)$. Platinum-containing combinations have evolved into a standard of care $(26,27,35)$, typically administered concurrently $(14,24,51)$. The issue of radiotherapy fractionation has also been studied extensively (conventional daily $1.8-2 \mathrm{~Gy}$ fractions to approximately 60-66 Gy, hyperfractionation, acceleration by more than one daily fraction, 
acceleration by hypofractionation) $(23,34,39)$. So far, conventional fractionation continues to be equivalent to altered fractionation. Overall treatment time increases when attempting dose escalation with conventional fractionation, and this factor might limit the efficacy of numerically more intense radiotherapy regimens (18). One possibility to reduce overall treatment time is the use of hypofractionation, either during the whole course of chemoradiation or for example by use of stereotactic boost radiotherapy $(52,53)$, thereby administering a high biologically effective dose within a standard time frame. The same problem of accelerated repopulation of cancer cells during prolonged treatment could explain the lack of benefit from sequential chemoand radiotherapy as compared to concurrent administration (51). Stereotactic radiotherapy is now also being studied for patients with locally recurrent disease (54). Differences in target volume definition have been addressed [avoiding elective lymph node regions (55), integrating positron emission tomography (PET) information (22)]. However, it was not possible to test all theoretically possible combinations of radiotherapy regimens, drugs, and drug doses (lower radiosensitizing doses compared to higher systemically active doses). That is why current guidelines offer physicians a choice of different, presumably equivalent treatment alternatives (56), which we will not discuss and repeat in detail.

Introduction of more sophisticated staging incl. PET, refinement of TNM categories, and increasing frequency of nonsquamous cell carcinoma histologies make it difficult to compare contemporary and historic patient groups. The prognostic and predictive impact of primary and total tumor volume, number of involved lymph nodes, and pattern of lymphatic spread incl. number of involved stations needs to be determined in a more rigorous fashion (57). Moreover, NSCLC is a biologically heterogeneous group of diseases. Even if molecular categories continue to evolve, therapeutic implications are already evident (use of pemetrexed or epidermal growth factor receptor inhibitors, and more targeted agents are currently being tested). As seen with bevacizumab (58), toxicity of full dose platinum-based chemoradiation plus additional agents might be prohibitive, depending on pathways targeted by new agents. The picture gets even more complicated when one adds host heterogeneity (age, comorbidity, nutrition status). Clearly, not all patients are suitable for the most efficacious concurrent regimens (59). In such cases, sequential treatment still might be considered, as is the case when initial

\section{REFERENCES}

1. Salama JK, Vokes EE. New radiotherapy and chemoradiotherapy approaches for non-small-cell lung cancer. $J$ Clin Oncol (2013) 31:1029-38. doi:10.1200/JCO.2012.44.5064

2. Brunese L, Greco B, Setola FR, Lassandro F, Guarracino MR, De Rimini $\mathrm{M}$, et al. Non-small cell lung cancer evaluated with quantitative contrast-enhanced CT and PET-CT: net enhancement and standardized uptake values are related to tumour size and histology. Med Sci Monit (2013)
19:95-101. doi:10.12659/MSM. 883759 jevic S. Radiotherapy alone vs. radiochemotherapy in patients with favorable prognosis of clinical stage IIIA non-smallcell lung cancer. Clin Lung Cancer (2013) 14:172-80. doi:10.1016/j.cllc.2012.10.002

4. van Meerbeeck JP, Surmont VF. Stage IIIA-N2 NSCLC: a review of its treatment approaches and future developments. Lung Cancer (2009) 65:257-67. doi:10.1016/j.lungcan.2009.02.007
3. Jeremic B, Milicic B, Milisavl-

tumor volume would necessitate prohibitively high normal lung dose.

At present, many open questions remain. Does addition of surgery to chemoradiation [an intensely studied paradigm (29, $36,41,43,46)$ ] provide better outcomes, and if so in patients with primarily resectable stage III disease and those with more advanced disease but favorable response to induction? Or is this approach relevant only for superior sulcus tumors (60)? Is radiation dose escalation still promising or a futile approach that only increases toxicity (18)? Esophagitis and pneumonitis are well known dose-limiting toxicities (61-64). Can proton therapy overcome limitations of other techniques $(19,21)$ ? Will pharmacological toxicity mitigation strategies ever make it into routine clinical practice (65)? Will innovative concepts of consolidation chemotherapy after chemoradiation perform better than previous attempts $(37,66,67)$ ? Is there a role for PET not only prior to treatment but also during chemoradiation, predicting efficacy, or allowing for treatment plan adaptation (17)? Can we identify those elderly patients who will tolerate intense combined modality treatment (68)? Both local failure resulting from surviving tumor stem cells and development of distant metastases contribute to the modest long-term survival after chemoradiation (69). Some of the studies reviewed here attempted to improve only one, others both sources of failure. Development of brain metastases is a threat to many patients with initial stage III disease. So far, prophylactic cranial radiotherapy has not improved overall survival $(70,71)$. Despite these challenges, progress has been achieved and much has been learned. Technological, molecular, and pharmacological progress provides a basis for new generations of clinical trials. Continued support by patients, health care providers, payors, and sponsors is necessary to pursue the bumpy yet successful way toward survival improvement.

\section{CONCLUSION}

Citation count might aid individuals who try to identify important studies to achieve this goal. Progress in chemoradiation development was largely driven by cooperative groups and some dedicated single institutions, which pursued their concepts through different stages of clinical trials, often culminating in successful phase III trials. The latter as well as meta-analyses are likely to change clinical practice and achieve high citation counts.

5. Ramnath N, Dilling TJ, Harris LJ, Kim AW, Michaud GC, Balekian AA, et al. Treatment of stage III non-small cell lung cancer: diagnosis and management of lung cancer, 3rd ed: American College of Chest Physicians evidencebased clinical practice guidelines. Chest (2013) 143:314S$40 . \quad$ doi:10.1378/chest.122360

6. Munshi A, Krishnatry R, Banerjee S, Agarwal JP. Stereotactic conformal radiotherapy in non-small cell lung cancer an overview. Clin Oncol (R
Coll Radiol) (2012) 24:556-68. doi:10.1016/j.clon.2012.03.009

7. Iyengar $\mathrm{P}$, Timmerman RD. Stereotactic ablative radiotherapy for non-small cell lung cancer: rationale and outcomes. $J$ Natl Compr Canc Netw (2012) 10:1514-20.

8. Inoue $\mathrm{T}$, Katoh $\mathrm{N}$, Onimaru $\mathrm{R}$, Shimizu S, Tsuchiya K, Suzuki $\mathrm{R}$, et al. Stereotactic body radiotherapy using gated radiotherapy with real-time tumor-tracking for stage I non-small cell lung cancer. Radiat Oncol (2013) 8:69. doi:10.1186/1748-717X-8-69 
9. Grills IS, Hope AJ, Guckenberger $M$, Kestin LL, Werner-Wasik $\mathrm{M}$, Yan D, et al. A collaborative analysis of stereotactic lung radiotherapy outcomes for early-stage non-small-cell lung cancer using daily online conebeam computed tomography image-guided radiotherapy. $J$ Thorac Oncol (2012) 7:1382-93. doi:10.1097/JTO.0b013e318260 e00d

10. Chen VJ, Oermann E, Vahdat S, Rabin J, Suy S, Yu X, et al. CyberKnife with tumor tracking: an effective treatment for high-risk surgical patients with stage I non-small cell lung cancer. Front Oncol (2012) 2:9. doi:10.3389/fonc.2012.00009

11. Lagerwaard FJ, Verstegen NE, Haasbeek CJ, Slotman BJ, Paul MA, Smit EF, et al. Outcomes of stereotactic ablative radiotherapy in patients with potentially operable stage I non-small cell lung cancer. Int $J$ Radiat Oncol Biol Phys (2012) 83:348-53. doi:10.1016/j.ijrobp.2011.06.2003

12. Durieux V, Gevenois PA. Bibliometric indicators: quality measurements of scientific publication. Radiology (2010) 255:34251. doi:10.1148/radiol.09090626

13. Nieder C, Astner ST, Grosu AL. Glioblastoma research 2006-2010: pattern of citation and systematic review of highly cited articles. Clin Neurol Neurosurg (2012) 114:1207-10. doi:10.1016/j.clineuro.2012.03.049

14. Curran WJ, Paulus R, Langer CJ, Komaki R, Lee JS, Hauser $\mathrm{S}$, et al. Sequential vs concurrent chemoradiation for stage III non-small cell lung cancer: randomized phase III trial RTOG 9410. J Natl Cancer Inst (2011) 103:1452-60. Cited 34 times. doi:10.1093/jnci/djr325

15. Blumenschein GR, Paulus R, Curran WJ, Curran WJ, Robert F, Fossella F, et al. Phase II study of cetuximab in combination with chemoradiation in patients with stage IIIA/B non-small-cell lung cancer: RTOG 0324. J Clin Oncol (2011) 29:2312-8. Cited 33 times. doi:10.1200/JCO.2010.31.7875

16. Govindan R, Bogart J, Stinchcombe T, Wang X, Hodgson L, Kratzke R, et al. Randomized phase II study of pemetrexed, carboplatin, and thoracic radiation with or without cetuximab in patients with locally advanced unresectable non-small-cell lung cancer: Cancer and Leukemia
Group B trial 30407. J Clin Oncol (2011) 29:3120-5. Cited 21 times. doi:10.1200/JCO.2010.33.4979

17. Huang W, Zhou T, Ma L, Sun $\mathrm{H}$ Gong H, Wang J, et al. Standard uptake value and metabolic tumor volume of $18 \mathrm{~F}-\mathrm{FDG}$ PET/CT predict short-term outcome early in the course of chemoradiotherapy in advanced non-small cell lung cancer. Eur J Nucl Med Mol Imaging (2011) 38:1628-35. Cited 16 times. doi:10.1007/s00259-011-1838-5

18. Guckenberger M, Wilbert J, Richter A, Baier K, Flentje M. Potential of adaptive radiotherapy to escalate the radiation dose in combined radiochemotherapy for locally advanced non-small cell lung cancer. Int J Radiat Oncol Biol Phys (2011) 79:901-8. Cited 15 times. doi:10.1016/j.ijrobp.2010.04.050

19. Chang JY, Komaki R, Lu C, Wen HY, Allen PK, Tsao A, et al. Phase 2 study of high-dose proton therapy with concurrent chemotherapy for unresectable stage III nonsmall cell lung cancer. Cancer (2011) 117:4707-13. Cited 14 times. doi:10.1002/cncr.26080

20. Hsu HS, Huang PI, Chang YL, Tzao C, Chen YW, Shih HC, et al. Cucurbitacin I inhibits tumorigenic ability and enhances radiochemosensitivity in nonsmall cell lung cancer-derived CD133-positive cells. Cancer (2011) 117:2970-85. Cited 14 times. doi:10.1002/cncr.25869

21. Sejpal S, Komaki R, Tsao A, Chang JY, Liao Z, Wei X, et al. Early findings on toxicity of proton beam therapy with concurrent chemotherapy for nonsmall cell lung cancer. Cancer (2011) 117:3004-13. Cited 13 times. doi:10.1002/cncr.25848

22. van Loon J, van Baardwijk A, Boersma L, Ollers M, Lambin P, De Ruysscher D. Therapeutic implications of molecular imaging with PET in the combined modality treatment of lung cancer. Cancer Treat Rev (2011) 37:331-43. Cited 12 times. doi:10.1016/j.ctrv.2011.01.005

23. Baumann M, Herrmann T, Koch R, Matthiessen W, Appold S, Wahlers B, et al. Final results of the randomized phase III CHARTWEL-trial (ARO 97-1) comparing hyperfractionatedaccelerated versus conventionally fractionated radiotherapy in non-small cell lung cancer (NSCLC). Radiother Oncol (2011)
100:76-85. Cited 12 times. doi:10.1016/j.radonc.2011.06.031

24. Non-small cell lung cancer collaborative group. Chemotherapy in non-small cell lung cancer: a meta-analysis using updated data on individual patients from 52 randomised clinical trials. BMJ (1995) 311:899-909. Cited 2733 times. doi:10.1136/bmj.311.7010.899

25. Pfister DG, Johnson DH, Azzoli CG, Sause W, Smith TJ, Baker $\mathrm{S}$ Jr, et al. American Society of Clinical Oncology treatment of unresectable non-small-cell lung cancer guideline: update 2003. J Clin Oncol (2004) 22:330-53. Cited 985 times. doi:10.1200/JCO.2004.09.053

26. Furuse K, Fukuoka M, Kawahara M, Nishikawa H, Takada Y, Kudoh S, et al. Phase III study of concurrent versus sequential thoracic radiotherapy in combination with mitomycin, vindesine, and cisplatin in unresectable stage III non-small-cell lung cancer. J Clin Oncol (1999) 17:2692-9. Cited 926 times.

27. Schaake-Koning C, van den Bogaert W, Dalesio O, Festen J, Hoogenhout J, van Houtte P, et al. Effects of concomitant cisplatin and radiotherapy on inoperable non-small-cell lung cancer. N Engl J Med (1992) 326:524-30. Cited 858 times. doi:10.1056/NEJM19920220326 0805

28. Dillman RO, Herndon J, Seagren SL, Eaton WL Jr, Green MR. Improved survival in stage III non-small-cell lung cancer: sevenyear follow-up of Cancer and Leukemia Group B (CALGB) 8433 trial. J Natl Cancer Inst (1996) 88:1210-5. Cited 657 times. doi:10.1093/jnci/88.17.1210

29. Albain KS, Rusch VW, Crowley JJ, Rice TW, Turrisi AT III, Weick JK, et al. Concurrent cisplatin/etoposide plus chest radiotherapy followed by surgery for stages IIIA(N2) and IIIB nonsmall-cell lung cancer: mature results of Southwest Oncology Group phase II study 8805. J Clin Oncol (1995) 13:1880-92. Cited 566 times.

30. Le Chevalier T, Arriagada R, Quoix E, Ruffie P, Martin M, Tarayre $\mathrm{M}$, et al. Radiotherapy alone versus combined chemotherapy and radiotherapy in nonresectable non-small-cell lung cancer: first analysis of a randomized trial in 353 patients. I Natl Cancer
Inst (1991) 83:417-23. Cited 557 times. doi:10.1093/jnci/83.6.417

31. Sause WT, Scott C, Taylor S, Johnson D, Livingston R, Komaki $\mathrm{R}$, et al. Radiation Therapy Oncology Group (RTOG) 88-08 and Eastern Cooperative Oncology Group (ECOG) 4588: preliminary results of a phase III trial in regionally advanced, unresectable non-small-cell lung cancer. J Natl Cancer Inst (1995) 87:198-205. Cited 547 times. doi:10.1093/jnci/87.3.198

32. American Society of Clinical Oncology. Clinical practice guidelines for the treatment of unresectable non-small-cell lung cancer. J Clin Oncol (1997) 15:29963018. Cited 487 times.

33. Keller SM, Adak S, Wagner $\mathrm{H}$, Herskovic A, Komaki R, Brooks $\mathrm{BJ}$, et al. A randomized trial of postoperative adjuvant therapy in patients with completely resected stage II or IIIA non-small-cell lung cancer. N Engl J Med (2000) 343:1217-22. Cited 326 times. doi:10.1056/NEJM20001026343 1703

34. Jeremic B, Shibamoto Y, Acimovic L, Milisavljevic S. Hyperfractionated radiation therapy with or without concurrent low-dose daily carboplatin/etoposide for stage III non-small-cell lung cancer: a randomized study. J Clin Oncol (1996) 14:1065-70. Cited 305 times.

35. Vokes EE, Herndon JE II, Crawford J, Leopold KA, Perry MC, Miller AA, et al. Randomized phase II study of cisplatin with gemcitabine or paclitaxel or vinorelbine as induction chemotherapy followed by concomitant chemoradiotherapy for stage IIIB non-small-cell lung cancer: Cancer and Leukemia Group B study 9431. J Clin Oncol (2002) 20:4191-8. Cited 255 times. doi:10.1200/JCO.2002.03.054

36. Eberhardt W, Wilke H, Stamatis G, Stuschke M, Harstrick A, Menker $\mathrm{H}$, et al. Preoperative chemotherapy followed by concurrent chemoradiation therapy based on hyperfractionated accelerated radiotherapy and definitive surgery in locally advanced non-small-cell lung cancer: mature results of a phase II trial. J Clin Oncol (1998) 16:62234. Cited 255 times

37. Gandara DR, Chansky K, Albain KS, Leigh BR, Gaspar LE, Lara $\mathrm{PN} \mathrm{Jr}$, et al. Consolidation docetaxel after concurrent 
chemoradiotherapy in stage IIIb non-small-cell lung cancer: phase II Southwest Oncology Group Study S9504. J Clin Oncol (2003) 21:2004-10. Cited 237 times. doi:10.1200/JCO.2003.04.197

38. Mac Manus MP, Hicks RJ, Matthews JP, McKenzie A, Rischin D, Salminen EK, et al. Positron emission tomography is superior to computed tomography scanning for response-assessment after radical radiotherapy or chemoradiotherapy in patients with non-small-cell lung cancer. J Clin Oncol (2003) 21:1285-92. Cited 236 times. doi:10.1200/JCO.2003.07.054

39. Jeremic B, Shibamoto Y, Acimovic L, Djuric L. Randomized trial of hyperfractionated radiation therapy with or without concurrent chemotherapy for stage III nonsmall-cell lung cancer. JClin Oncol (1995) 13:452-8. Cited 236 times.

40. Fournel P, Robinet G, Thomas P, Souquet PJ, Léna H, Vergnenégre A, et al. Randomized phase III trial of sequential chemoradiotherapy compared with concurrent chemoradiotherapy in locally advanced non-small-cell lung cancer: Groupe Lyon-SaintEtienne d'Oncologie ThoraciqueGroupe Français de PneumoCancérologie NPC 95-01 study. J Clin Oncol (2005) 23:5910-7. Cited 230 times.

41. Choi NC, Carey RW, Daly W, Mathisen D, Wain J, Wright C, et al. Potential impact on survival of improved tumor downstaging and resection rate by preoperative twice-daily radiation and concurrent chemotherapy in stage IIIA non-small-cell lung cancer. J Clin Oncol (1997) 15:712-22. Cited 223 times.

42. Zatloukal P, Petruzelka L, Zemanova M, Havel L, Janku F, Judas L, et al. Concurrent versus sequential chemoradiotherapy with cisplatin and vinorelbine in locally advanced non-small cell lung cancer: a randomized study. Lung Cancer (2004) 46:87-98. Cited 222 times. doi:10.1016/j.lungcan.2004.03.004

43. van Meerbeeck JP, Kramer GW, van Schil PE, Senan S; EORTC-Lung Cancer Group. Randomized controlled trial of resection versus radiotherapy after induction chemotherapy in stage IIIA-N2 non-small-cell lung cancer. J Natl Cancer Inst (2007) 99:442-50. Cited 208 times. doi:10.1093/jnci/djk093
44. Pritchard RS, Anthony SP. Chemotherapy plus radiotherapy compared with radiotherapy alone in the treatment of locally advanced, unresectable, non-small-cell lung cancer: a meta-analysis. Ann Intern Med (1996) 125:723-9. Cited 207 times. doi:10.7326/ 0003-4819-125-9-19961101000003

45. Marino P, Preatoni A, Cantoni A. Randomized trials of radiotherapy alone versus combined chemotherapy and radiotherapy in stages IIIa and IIIb nonsmall cell lung cancer: a meta-analysis. Cancer (1995) 76:593-601. Cited 203 times. doi:10.1002/10970142(19950815)76:4<593::AIDCNCR2820760409>3.0.CO;2-N

46. Albain KS, Swann RS, Rusch VW, Turrisi AT III, Shepherd FA, Smith C, et al. Radiotherapy plus chemotherapy with or without surgical resection for stage III non-small-cell lung cancer: a phase III randomised controlled trial. Lancet (2009) 374:379-86. Cited 200 times. doi:10.1016/S01406736(09)60737-6

47. Arriagada R, Le Chevalier $\mathrm{T}$, Quoix E, Quoix E, Ruffie P, de Cremoux H, et al. ASTRO plenary: effect of chemotherapy on locally advanced non-small cell lung carcinoma: a randomized study of 353 patients. Int $J$ Radiat Oncol Biol Phys (1991) 20:1183-90. Cited 199 times. doi:10.1016/03603016(91)90226-T

48. Belani CP, Choy $\mathrm{H}$, Bonomi P, Scott C, Travis P, Haluschak J, et al. Combined chemoradiotherapy regimens of paclitaxel and carboplatin for locally advanced non-small-cell lung cancer: a randomized phase II locally advanced multi-modality protocol. J Clin Oncol (2005) 23:5883-91. Cited 185 times. doi:10.1200/JCO.2005.55.405

49. Mattson K, Holsti LR, Holsti P, Jakobsson M, Kajanti M, Liippo $\mathrm{K}$, et al. Inoperable non-small cell lung cancer: radiation with or without chemotherapy. Eur J Cancer (1988) 24:477-82. Cited 116 times. doi:10.1016/S0277-5379(98) 90020-7

50. Soresi E, Clerici M, Grilli R, Borghini U, Zucali R, Leoni $\mathrm{M}$, et al. A randomized clinical trial comparing radiation therapy vs. radiation therapy plus cis-dichlorodiammine platinum (II) in the treatment of locally advanced non-small cell lung cancer. Semin Oncol (1988) 15:20-5. Cited 94 times.

51. Aupérin A, Le Péchoux C, Rolland E, Curran WJ, Furuse $\mathrm{K}$, Fournel $\mathrm{P}$, et al. Metaanalysis of concomitant versus sequential radiochemotherapy in locally advanced non-small-cell lung cancer. J Clin Oncol (2010) 28:2181-90. Cited 132 times. doi:10.1200/JCO.2009.26.2543

52. Beli I, Koukourakis G, Platoni $\mathrm{K}$, Tolia M, Kelekis N, Kouvaris J, et al. Hypofractionated radiotherapy in non small cell lung cancer: a review of the current literature. Rev Recent Clin Trials (2010) 5:103-11. doi:10.2174/157488710791233608

53. Feddock J, Arnold SM, Shelton BJ, Sinha P, Conrad G, Chen L, et al. Stereotactic body radiation therapy can be used safely to boost residual disease in locally advanced nonsmall cell lung cancer: a prospective study. Int $J$ Radiat Onco Biol Phys (2013) 85:1325-31. doi:10.1016/j.ijrobp.2012.11.011

54. Mantel F, Flentje M, Guckenberger M. Stereotactic body radiation therapy in the re-irradiation situation - a review. Radiat Oncol (2013) 8:7. doi:10.1186/1748-717X-8-7

55. Yuan S, Sun X, Li M, Yu J, Ren $\mathrm{R}, \mathrm{Yu} \mathrm{Y}$, et al. A randomized study of involved-field irradiation versus elective nodal irradiation in combination with concurrent chemotherapy for inoperable stage III nonsmall cell lung cancer. Am J Clin Oncol (2007) 30:239-44. Cited 81 times. doi:10.1097/01.coc.0000256691. 27796.24

56. Ettinger DS, Akerley W, Bepler G, Blum MG, Chang A, Cheney RT, et al. Non-small cell lung cancer: clinical practice guidelines in oncology. JNCCN (2010) 8:771801. Cited 81 times.

57. Liao S, Penney BC, Wroblewski K, Zhang H, Simon CA, Kampalath R, et al. Prognostic value of metabolic tumor burden on 18F-FDG PET in nonsurgical patients with non-small cell lung cancer. Eur J Nucl Med Mol Imaging (2012) 39:27-38. doi:10.1007/s00259-011-1934-6

58. Spigel DR, Hainsworth JD, Yardley DA, Raefsky E, Patton J, Peacock N, et al. Tracheoesophageal fistula formation in patients with lung cancer treated with chemoradiation and bevacizumab. J Clin Oncol (2010) 28:43-8. Cited 71 times. doi:10.1200/JCO.2009.24.7353

59. Brunelli A, Charloux A, Bolliger CT, Rocco G, Sculier JP, Varela G, et al. ERS/ESTS clinical guidelines on fitness for radical therapy in lung cancer patients (surgery and chemo-radiotherapy). Eur Respir J (2009) 34:17-41. Cited 97 times. doi:10.1183/09031936.00184308

60. Rusch VW, Giroux DJ, Kraut MJ, Crowley J, Hazuka M, Johnson D, et al. Induction chemoradiation and surgical resection for nonsmall cell lung carcinomas of the superior sulcus: initial results of Southwest Oncology Group Trial 9416 (Intergroup Trial 0160). J Thorac Cardiovasc Surg (2001) 121:472-83. Cited 158 times. doi:10.1067/mtc.2001.112465

61. Roach M III, Gandara DR, Yuo HS, Swift PS, Kroll S, Shrieve DC, et al. Radiation pneumonitis following combined modality therapy for lung cancer: analysis of prognostic factors. J Clin Oncol (1995) 13:2606-12. Cited 170 times.

62. Tsujino $K$, Hirota $S$, Endo $M$, Obayashi K, Kotani Y, Satouchi $\mathrm{M}$, et al. Predictive value of dosevolume histogram parameters for predicting radiation pneumonitis after concurrent chemoradiation for lung cancer. Int $J$ Radiat Oncol Biol Phys (2003) 55:110-5. Cited 152 times. doi:10.1016/S03603016(02)03807-5

63. Wang S, Liao Z, Wei X, Liu HH, Tucker SL, Hu CS, et al. Analysis of clinical and dosimetric factors associated with treatmentrelated pneumonitis (TRP) in patients with non-small-cell lung cancer (NSCLC) treated with concurrent chemotherapy and three-dimensional conformal radiotherapy (3D-CRT). Int $J$ Radiat Oncol Biol Phys (2006) 66:1399-407. Cited 128 times. doi:10.1016/j.ijrobp.2006.07.1337

64. Singh AK, Lockett MA, Bradley JD. Predictors of radiationinduced esophageal toxicity in patients with non-smallcell lung cancer treated with three-dimensional conformal radiotherapy. Int J Radiat Oncol Biol Phys (2003) 55:337-41. Cited 89 times. doi:10.1016/S03603016(02)03937-8

65. Movsas B, Scott C, Langer C, Werner-Wasik M, Nicolaou N, Komaki R, et al. Randomized trial of amifostine in locally 
advanced non-small-cell lung cancer patients receiving chemotherapy and hyperfractionated radiation: Radiation Therapy Oncology Group Trial 98-01. J Clin Oncol (2005) 23:2145-54. Cited 83 times. doi:10.1200/JCO.2005. 07.167

66. Kelly K, Chansky K, Gaspar LE, Albain KS, Jett J, Ung YC, et al. Phase III trial of maintenance gefitinib or placebo after concurrent chemoradiotherapy and docetaxel consolidation in inoperable stage III nonsmall-cell lung cancer: SWOG S0023. J Clin Oncol (2008) 26:2450-6. Cited 180 times. doi:10.1200/JCO.2007.14. 4824

67. Hanna N, Neubauer M, Yiannoutsos C, McGarry R, Arseneau J, Ansari R, et al. Phase III study of cisplatin, etoposide, and concurrent chest radiation with or without consolidation docetaxel in patients with inoperable stage III non-small-cell lung cancer: the Hoosier Oncology Group and U.S. Oncology. J Clin Oncol (2008) 26:575560. Cited 112 times. doi:10. 1200/JCO

68. Schild SE, Stella PJ, Geyer SM, Bonner JA, McGinnis WL, Mailliard JA, et al. The outcome of combined-modality therapy for stage III nonsmall-cell lung cancer in the elderly. J Clin Oncol (2003) 21:3201-6. Cited 124 times. doi:10.1200/JCO.2003.12.019

69. Aydiner A, Sen F, Saglam EK, Oral EN, Eralp Y, Tas F, et al. Induction chemotherapy with triweekly docetaxel and cisplatin followed by concomitant chemoradiotherapy with or without surgery in stage III non-small-cell lung cancer: a phase II study. Clin
Lung Cancer (2011) 12:286-92. doi:10.1016/j.cllc

70. Stuschke M, Eberhardt W, Pöttgen C, Stamatis G, Wilke H, Stüben $\mathrm{G}$, et al. Prophylactic cranial irradiation in locally advanced nonsmall-cell lung cancer after multimodality treatment: long-term follow-up and investigations of late neuropsychologic effects. Clin Oncol (1999) 17:2700-9. Cited 132 times.

71. Robnett TJ, Machtay M, Stevenson JP, Algazy KM, Hahn SM. Factors affecting the risk of brain metastases after definitive chemoradiation for locally advanced nonsmall-cell lung carcinoma. J Clin Oncol (2001) 19:1344-9. Cited 91 times.

Conflict of Interest Statement: The authors declare that the research was conducted in the absence of any commercial or financial relationships that could be construed as a potential conflict of interest.

Received: 26 April 2013; paper pending published: 12 June 2013; accepted: 21 June 2013; published online: 09 July 2013.

Citation: Nieder C, Pawinski $A$ and Andratschke NH (2013) Combined radio- and chemotherapy for non-small cell lung cancer: systematic review of landmark studies based on acquired citations. Front. Oncol. 3:176. doi: 10.3389/fonc.2013.00176

This article was submitted to Frontiers in Radiation Oncology, a specialty of Frontiers in Oncology.

Copyright (c) 2013 Nieder, Pawinski and Andratschke. This is an open-access article distributed under the terms of the Creative Commons Attribution License, which permits use, distribution and reproduction in other forums, provided the original authors and source are credited and subject to any copyright notices concerning any third-party graphics etc. 